\title{
Factors Affecting the International Students Success in a First-Year Mathematics Courses at ZUST
}

\author{
Humphrey Manhamo, Atsou Komla Herve Agbemenou, Shuhui Wu, and Jianhua Wei
}

\begin{abstract}
In recent years, there is a tremendous increasing among international students to study in Chinese universities, where who may experience considerable difficulties and challenges, particularly during the first-year study. However, there is still incipient research in this area. Thus, it is high time to explore the factors that might affect the international students' learning performances and outcomes of Mathematics courses. The investigation is based on a sample of 140 undergraduate students from different disciplines at Zhejiang University of Science and Technology. The finding constitutes a range of contributory factors which affect their adaptions and opens new paths for future research on the international education.
\end{abstract}

Index Terms-Mathematic courses, international student, first-year.

\section{INTRODUCTION}

In the era of globalization, there are more and more people who choose to study abroad. Recently, the number of people who choose China as their study destination is increase tremendously. According to [1], in 2015 there were nearly 400,000 international students from 202 countries or regions studied in Chinese institutions, a 50 percent increase compared with the year 2010. In [2], it is reported that the number of international students enrolled in Chinese institutions increased by 11.35 percent to 442,773 students in 2016, with 45,138 more students than in 2015 . On the other hand, it has been recognized that higher education is more important today than at any time in the past. As stated in a report by the World Bank [3], "As knowledge becomes more important, so does higher education. Countries need to educate more of their young people to higher standard-a degree is now a basic qualification for many skilled jobs. The quality of knowledge generated within higher education institutions, and its availability to the wider economy, is becoming increasingly critical to national competitiveness" (p. 9 of [3]).

Therefore, the demands for Chinese institutions are higher and are continuing to rise. Even in the USA, there are

Manuscript received September 20, 2017; revised December 13, 2017. This work was supported in part under Grant (2016R415033, 2011IB-a3, Linear Algebra B).

Humphrey Manhamo and Shuhui Wu are with School of Science, Zhejiang University of Science and Technology, 318 Liuhe Road, Hangzhou, Zhejiang, China (e-mail: manhamoh@ @otmail.com, s.wu@ zust.edu.cn).

Atsou Komla Herve Agbemenou is with School of Humanities and International Education, Zhejiang University of Science and Technology, 318 Liuhe Road, Hangzhou, China, 310023, (e-mail: hevrardo@gmail.com).

Jianhua Wei is with International Student Affairs Center, Zhejiang University of Science and Technology, 318 Liuhe Road, Hangzhou, Zhejiang, China, 310023 (e-mail: weijianhua@zust.edu.cn ). approximately one fifth of all first-year students who started at an institution that confers bachelor's degree did not return for a second year at that institution [4]. According to Council on Higher Education 2013 [5], among the black students who access higher education, there is only $20 \%$ students who complete their respective degrees in the prescribed time, $30 \%$ take a further 2 to 3 years to finish, and 50\% drop out before obtaining their qualifications. What is more, in the book [6], "It is little wonder then, that with the increase in student diversity internationally, educationists who seek to enhance student success should pay attention to the moment of greatest transition, the first year of study" (p. 3). In fact, there is lots of research on the first-year study of university, see the references [7]-[21], for example.

There are many factors which are contributed to this situation. First-year students do not always understand the difference studying at a university and studying at a high school or the demands of the university-level teaching-learning environment. Specially, Mathematics courses are among the most difficult courses for most the students. On the other hand, mathematics courses are used by virtually most degree programs as the basis for fundamental knowledge. It is even harder for the international students when they study in a different culture context from their original culture. In order to support international students' study effectively, we need more information regarding the nature to students' study styles and preferences, especially in the critical first year, and the first year's relation to study success. It is high time to explore the factors affecting the success learning of international students at Chinese universities.

The present study is to investigate the factors which affect the learning outcomes of the international students at Zhejiang University of Science and Technology (ZUST). Though there are way too many contributory factors that may be considered, our study will focus solely on those factors that we presume to be the most significant factors according to the experience of management and the experience of teaching international students at ZUST and some literature.

\section{CONCEPTUAL FRAMEWORK}

Zhejiang University of Science and Technology, based in Hangzhou, China, is the bases of this study. Situated in Hangzhou, ZUST has had the number of foreign students increasing each year and each one of these years there has emerged new concerns about students' learning performance in Mathematics courses. Mathematics Fundamentals (or called pre-Calculus), Calculus, Linear Algebra, Probability theory are compulsory courses for all first-year international 
students at ZUST except Language students. In this paper, we will use survey data from these courses with regard to some statistical methods to assess the relationship between the factors identified and student performance. The study will be specific to first year mathematics courses, though second, third and fourth years also participated by providing responses from their own first year experiences, and will be based on responses from international students only. There are specific aims of this study which may be classified into three categories, past, present and future:

Past - To explore the extent to which each student mastered mathematics prior to coming to ZUST.

Present - The study will focus on the current teaching methods as well as resources available and how they affect students' learning performances and outcomes.

Future - The study will also focus on the extent to which Mathematics has implications to students' future studies and how much their respective majors will include math in the future.

\section{THE MATERIAL}

The study has been carried out using a questionnaire. 18 questions were given to each student and with ample time to complete the questionnaire. The questionnaire was created such that all the questions are directly linked to one or more main points from the ones already identified. A sample of Students from Civil Engineering, Actuarial Science, Computer Science and Economics took part in the questionnaire for which only international students participated. The questions were given to students whilst they were in classes. Language majors were not included in this study since students from these majors normally would not take a mathematics course at ZUST. From the results of this study, certain factors were drawn from what students ascertain to have influenced their performances in class. From the survey, a total of 131 students participated. The distribution of questions was random and ensured that all responses, on average, came from equal representatives from different majors.

\section{Summary Statistics}

The data in the following table, Table I, summarizes the responses and the percentage statistic denotes the portion of the sample of students who made a particular respond as a percentage of the total number of students who took part in the survey. There were some survey papers which had 'spoiled' responses where students put a response on both options available or provide statement type of information on those options requiring only 'Yes' or 'No' or in some cases students failed to put a response altogether. These were treated as 'spoiled' but they had little significant to affect the overall statistical outcome. There were options requiring 'Often', 'Sometimes' or 'Rarely' which are not included in this summary statistics. These statistics were analyzed separately in this paper and the same goes for the question that required a respond on 'Fail', 'Pass' or 'Outstanding'. All the information in the summary statistics was acquired to explore the main objective of this writing as well as to evaluate and give evidence to the main points that we have already identified and mentioned as affecting foreign students' success in a first year Mathematics courses at ZUST.

TABLE I: DATA REFLECTING RESPONSES TO DIFFERENT QUESTIONS

\begin{tabular}{|c|c|c|}
\hline Response on: & $\%$ Yes & $\% \mathrm{No}$ \\
\hline $\begin{array}{l}\text { Mathematics (such as Linear Algebra, } \\
\text { Calculus) a difficult course }\end{array}$ & 48.09 & 51.91 \\
\hline $\begin{array}{l}\text { Pre-university mathematics knowledge } \\
\text { was sufficient for university } \\
\text { mathematics }\end{array}$ & 62.60 & 37.40 \\
\hline $\begin{array}{l}\text { Mathematics was more challenging } \\
\text { compared to pre-university education }\end{array}$ & 44.27 & 55.73 \\
\hline $\begin{array}{l}\text { Methods used in mathematics classes at } \\
\text { university differ from those before } \\
\text { university }\end{array}$ & 74.05 & 25.95 \\
\hline $\begin{array}{l}\text { Feel comfortable with university } \\
\text { mathematics from the very beginning } \\
\text { of university }\end{array}$ & 54.20 & 45.80 \\
\hline Are curious of the material in classes & 68.70 & 29.77 \\
\hline $\begin{array}{l}\text { Lecturers encouraged them to } \\
\text { understand the contents in depth }\end{array}$ & 58.02 & 41.22 \\
\hline $\begin{array}{l}\text { Lecturers speak English well so that } \\
\text { you could follow easily }\end{array}$ & 54.96 & 45.04 \\
\hline $\begin{array}{l}\text { There are enough mathematics } \\
\text { resources at ZUST }\end{array}$ & 47.33 & 52.67 \\
\hline $\begin{array}{l}\text { The mathematics lecturers use more } \\
\text { than one resource in classes }\end{array}$ & 38.17 & 61.83 \\
\hline $\begin{array}{l}\text { Mathematics lecturers try to show the } \\
\text { real-world problems application of } \\
\text { mathematics theory }\end{array}$ & 42.75 & 57.25 \\
\hline $\begin{array}{l}\text { Had too much workload to fully focus } \\
\text { on mathematics }\end{array}$ & 61.83 & 38.17 \\
\hline Got many mathematics assignments & 82.44 & 16.79 \\
\hline
\end{tabular}

\section{FIGURES}

\section{A. Student Background Gap}

The data below shows the different pass rates drawn from the questionnaire. As seen from Table II, most students managed to pass high school/pre-university Mathematics before they came to ZUST. Whilst very few said that they failed mathematics, a good potion had outstanding results which suggest that a lot of students at ZUST are, at the very least, expected not to struggle with mathematics study at the beginning of their university studies.

TABLE II: PRE-UNIVERSITY SCORES

\begin{tabular}{|l|l|l|}
\hline Category & $\begin{array}{l}\text { Number of students } \\
\text { (out of 131) }\end{array}$ & Percentage \\
\hline Outstanding & 87 & 66.4 \\
\hline Pass & 33 & 25.2 \\
\hline Fail & 8 & 6.1 \\
\hline No Response & 3 & 2.3 \\
\hline
\end{tabular}

Surprisingly only $54.2 \%$ students said that they were comfortable with university Mathematics from the beginning, which raises great concern given the overwhelming percentage of those who passed their pre-university Mathematics courses. To get a better understanding of why this might be the case we explore the percentage of those who felt that the methods used in mathematics classes at ZUST are different from those they had gotten used to before. It is not surprising that $74.05 \%$ agreed that methods used in classes 
are different from pre-university education (Table I) which gives part of the explanation why students who have passed their mathematics exams prior to coming to ZUST have struggled with preliminary curriculum. In [7], the study ran a correlation analysis and found out that how well students performed in their matriculation mathematics was positively, but weakly associated with their MAT105 which confirms the results of the survey.

\section{B. Classroom and Lectures}

The survey has reflected that students have been cognitively engaged in classes, which has showed that around three out ten students who are curious of the things learned in their classes. However, surprisingly, it is reported that $54.96 \%$ of students clearly understand the type of English used by their teachers, which goes against the general knowledge that some Chinese teachers struggle teaching foreign students. On the other hand, $45.04 \%$ of students said that they do not understand the English teachers speak. This is a big potion to worry about teachers' abilities and skills of communication in classes. This is especially given the fact that $68.7 \%$ are curious about the classes but at the end of the day a good number of these students go home with their thirst and curiosity for knowledge hampered due to misinterpretation and mistranslation of Mathematical knowledge from Chinese basis to English.

It is reported that an overwhelming number of students, $57.2 \%$ think that teachers do not try their best to use real-world problems application of Mathematics theory. It is also true that students enjoy learning more and more when teachers demonstrate some realistic real-world applications of Mathematics theories. On the other hand, they wrestle with the pure theories. Mathematics, in general, helps students to think logically. For example, Algebra also helps students picture complicated concepts and relationships through creating and understanding graphic presentations of data. Most of students enjoy learning more, who are more likely to participate in tasks when their teachers employ active realistic strategies. In addition, students learn fairly well when classroom practices and theory explanations are being drawn on students' already existing knowledge and real-world experiences.

\section{Students Interaction}

Collaboration among students working together in pairs or small groups to help one another also has been associated with increased engagement and learning. There are $51.15 \%$ of students said that they sometimes discussed mathematics problems with their peers whilst $29.77 \%$ said they did this more regularly and only $19.08 \%$ said they rarely/never engaged in mathematics discussions with their peers. When students can put their heads together rather than work in isolation, they are more receptive to challenging assignments.

Table III below shows how students came together with their peers either working out mathematical problems or having a general mathematics quality circle. It is not so surprising that 'sometimes' is the mode of this distribution since we can perceive that students try to make up for lecture's deficiencies by trying to bring ideas together and tackle mathematics problems on their own understanding. In addition, students who rarely meet up for discussions are the minority from the results we obtained. From the survey, it seems that over the long term that students were more likely to be engaged in the classroom when they were asked to conduct experiments, participate in educational arguments and researches as $69.12 \%$ of the positive answers were from the seniors, year 3 and a small number of year 4 students.

TABLE III: FREQUENCY OF MATHEMATICS DISCUSSIONS

\begin{tabular}{|l|l|l|}
\hline Category & $\begin{array}{l}\text { Number of students } \\
\text { (out of 131) }\end{array}$ & Percentage \\
\hline Often & 39 & 29.8 \\
\hline Sometimes & 67 & 51.1 \\
\hline Rarely & 25 & 19.1 \\
\hline
\end{tabular}

\section{Students' Attitude}

It is indicated that a number of students struggled with the courses from the beginning. They were with positive attitude towards mathematics as showed from their interaction habits and curiosity towards the courses. These attitudes, however, normally tend to become less positive as students get settled with university life, find new friends, and frequently become negative especially given the poor class attendances. It seems that the pressure exerted on students to cope with highly demanding tasks, often at a pace beyond their ambition, together with peer pressure and the desire to go to clubs, and so on, have a bearing on how they behave towards mathematics. The junior school years are the most crucial period in the course of development of students' behavior towards mathematics, meaning that teachers should promote the students' positive attitudes and high achievement.

The two tables below show how students have been helping themselves with self-work and completing assignments. From Table I we can see that about $61.83 \%$ of the students said that they had too much workload to fully focus on Mathematics study. The workload includes assignments from other non-related courses, official activities at university as well as the number of courses that they are taking per semester. It is, of course, not surprising that $82.44 \%$ feels that they get too many assignments. In fact, they have too much workload which is demonstrated by Table IV and V. A large number of students, surprisingly, answered that they often completed their assignments and even go on to do extra mathematics problems at their own spare time. This, obviously, calls for more exploration and evidence to the claim that students have too much workload to fully focus on Mathematics.

TABLE IV: COMPLETION OF ASSIGNMENTS

\begin{tabular}{|l|l|l|}
\hline Category & $\begin{array}{l}\text { Number of students } \\
\text { (out of 131) }\end{array}$ & Percentage \\
\hline Often & 93 & 71.0 \\
\hline Sometimes & 29 & 22.1 \\
\hline Rarely & 9 & 6.9 \\
\hline
\end{tabular}

TABLE V: EXTRA PRoBLEMS AFTER Class

\begin{tabular}{|l|l|l|}
\hline Category & $\begin{array}{l}\text { Number of students } \\
\text { (out of 131) }\end{array}$ & Percentage \\
\hline Often & 50 & 38.2 \\
\hline Sometimes & 61 & 46.6 \\
\hline Rarely & 20 & 15.2 \\
\hline
\end{tabular}




\section{E. University Resources}

ZUST have one foreign study room filled with foreign, English written books and resources. During this past decade, ZUST has just been moving more and more into enrolling international students and it makes sense to notice that the university doesn't have many rooms with English based resources. Though there are a couple of other rooms in the library, where also have a countable number of English based books. A large pile of those books is mathematics or at least for mathematics related study. However, foreign students hardly use that single room for study, based on quantitative research information. The rooms are hardly filled by foreign students at any time of a semester except during the examination period.

Only $47.33 \%$ of the students said that there were enough resources while only $38.17 \%$ said that teachers used more than one resource in classes. The negative responses is largely due to the fact that most of the books and resources that were provided at the university were either not related to specific courses offered at ZUST or were for more advanced learners. An interview with the third grade Actuarial Students yielded some interesting facts. All of them said that there has never found any actuarial related book in the library, which is a very worrying fact.

\section{F. Other Factors}

This study, in all the efforts, does not reveal all the contributory factors that affect first year students' success in mathematics courses. There are factors that are correlated with the factors analyzed above and also have a bearing on student success. The factors identified and analyzed by this study are only those perceived as the most affecting. This, therefore, calls for a mention of possible additional factors that may be considered in analyzing the topic.

\section{1) Class attendance}

Poor class attendance obviously may be assumed to hinder success while attending class promotes success. The most efficient way for a student to be informed is by attending class and gets updated with the syllabus. Poor time management by students and work load might cause poor attendance. But, it is also important to point out that many students seek extra financial provision by doing part-time jobs that might get in the way of study. A study of class attendance and its influence cited laziness as reason for poor attendance [8].

\section{2) Motivation}

In [22], the motivation is defined as "cognitive persistence: the drive, tendency, or desire to undertake or complete a task, expend effort, and do a quality job". Motivation is one of the factors that people, in general, rely on to do and complete tasks. At university, motivation is a crucial component for student success. Mathematics is intense and tiring that the level of motivation may well determine how a student is going to behave towards studying it.

\section{3) Social life and general well-being}

University social life is one of the most anticipated things by students. Generally, students anticipate having their most active social period at university. This includes finding new friends, romantic relationships, going to clubs, doing some sporting activities, joining some social circles and the list goes on. The regression model ran in [23] shows that excessive sporting activity and involvement in clubs and organizations by students does not have a significant effect on academic performance. While social life does not require a significant effect. In short, students who manage to control their social lives tend to remain focused on academic studies than those who don't. Social life is one of the main things that control a student life especially first year students. This, therefore, means that social life and general well-being might well be a contributory factor affecting foreign student success in a first-year mathematics course at ZUST.

\section{CONCLUSION}

This study serves as a bridge and starting point for bringing together international students and the administration of ZUST, teachers in particular. In essence, the responses brought on by students according to their perceptions of Mathematics learning and lecture experiences at ZUST provides a basis for further research into how these perceptions have come about, and what influences they might have in affecting learning and teaching approaches and subsequent learning outcomes. The results of this study suggest that the teacher-student relationship need to improve academic wise.

From the viewpoint of all participants, Mathematics is neither a hard nor easy course $(48.09 \%$ said it is difficult whilst the remainder said it is not) but the combination of adequate school resources and a more foreign oriented teaching style might boost success of first-year students in a Mathematics courses. Open communication, understanding between teacher and student as well as the use of real-world examples might improve students' understanding of mathematics course at ZUST.

Students have placed more importance on group discussion and self-study which might be the reason why they may have completed most assignments whereas a good portion of students reported that lecturers do not encourage them to understand the theory in depth. The most important question raised now is, 'Could this be due to the differences in teaching methods as suggested by $74.05 \%$ or is there a great concern on the way educational information is being executed by teachers to students?'

The limitations of this study were mainly structure of the questions in the survey that did not permit us to test for hypothesis and significance which is one of the most important and effective components of data analysis in statistics and regression. It is important to point out that our research was limited to our university, ZUST, and given that there is not much history for international students and also the fact that international students have only recently started to increase in numbers at this university, there is need for further exploration with enough evidence and data in future to support or make such claims as in this paper.

\section{ACKNOWLEDGMENT}

We would like to thank Ms. Deng for her considerable support and kindness. We also are thankful to all the students who participated in the survey. We wish all of them great 
success in Mathematics.

\section{REFERENCES}

[1] Moe. [Online].

Available: http://en.moe.gov.cn/News/Top_News/201611/t20161102_287359.ht $\mathrm{ml}$

[2] Moe.edu. [Online]. Available: http://www.moe.edu.cn/jyb_xwfb/xw_fbh/moe_2069/xwfbh_2017n/x wfb_170301/170301_sitj/201703/t20170301_297677.html

[3] World Bank, "Higher education in developing countries: Peril and promise," Washington, DC: The international Bank of Reconstruction and Development, 2000.

[4] R. Reason, "Student variables that predict retention: Recent research and new developments," NASPA Journal, vol. 46, no. 3, pp. 482-501, 2009.

[5] Council on Higher Education, "A proposal for undergraduate curriculum reform in South Africa: The case for a flexible curriculum structure," Report of the Task Team on Undergraduate Curriculum Structure, Pretoria: Council on Higher Education.

[6] B. Leibowitz, A. Merwe, and S. Schalkwyk, "Focus on first-year success: perspectives emerging from South Africa and beyond," Stellenbosh: SUN MeDIA.

[7] R. Kizito, J. Munyakazi, and C. Basuayi, "Factors affecting student success in a first-year mathematics course: A South African experience," International Journal of Mathematical Education in Science and Technology, vol. 47, no. 1, pp. 100-119, 2016.

[8] L. Steenkamp, R. Baard, and B. Frick, "Factors influencing success infirst-year accounting at a South African university: A comparison between lecturers' assumptions and students' perceptions," South African Journal of Accounting Research, vol. 23, no. 1, pp. 113-140, 2009.

[9] J. Cole, "Concluding comments about student transition to higher education," Higher Education, vol. 73, no. 3, pp. 539-551, 2017.

[10] J. Morrow and M. Ackermann, "Intention to persist and retention of first-year students: The importance of motivation and sense of belonging," College Student Journal, vol. 46, no. 3, pp. 483-49, 2012.

[11] National Survey of Student Engagement, Topical module: First-year experience \& senior transitions, Bloomington: Indiana University.

[12] V. McGhie, "Entering university studies: identifying enabling factors for a successful transition from school to university," Higher Education, vol. 73, no. 3, pp. 407-422, 2017.

[13] A. Bowles, R. Fisher, R. McPhail, D. Rosenstreich, and A. Dobson, "Staying the distance: students' perceptions of enablers of transition to higher education," Higher Education Research \& Development, vol. 33 no. 2, pp. 212-225, 2014.

[14] K. Nelson, "The first year in higher education-Where to from here?" The International Journal of the First Year in Higher Education, vol. 5, no. 2, p. 1, 2014.

[15] P. Steenkamp, S. Baard, and L. Frick, "A holistic investigation into a tutor programme in first-year Financial Accounting," Meditari Accountancy Research, vol. 20, no. 1, pp. 68-87, 2012.

[16] A. Haarala-Muhonen, M. Ruohoniemi, A. Parpala, E. Komulainen, and S. Lindblom-Ylänne, "How do the different study profiles of first-year students predict their study success, study progress and the completion of degrees?" Higher Education, vol. 74, no. 6, pp. 949-962, 2016.

[17] G. Sæle, I. Dahl, T. Sørlie, and O. Friborg, "Relationships between learning approach, procrastination and academic achievement amongst first-year university students," Higher Education, vol. 74, no. 5, pp. 757-774, 2016.

[18] L. Coertjens, T. Brahm, C. Trautwein, and S. Lindblom-Ylänne, "Students' transition into higher education from an international perspective," Higher Education, vol. 73, no. 3, pp. 357-369, 2017.

[19] S. Brooman and S. Darwent, "Measuring the beginning: A quantitative study of the transition to higher education," Studies in Higher Education, vol. 39, no. 9, pp. 1523-1541, 2014

[20] L. Postareff, M. Mattsson, S. Lindblom-Ylänne, and T. Hailikari, "The complex relationship between emotions, approaches to learning, study success and study progress during the transition to university," Higher Education, vol. 73, no. 3, pp. 441-457, 2017.

[21] K. Pettersson, M. Svedin, M. Scheja, and O. Bälter, "Approaches to studying in first-year engineering: comparison between inventory scores and students' descriptions of their approaches through interviews," Higher Education, pp. 1-12, 2017.

[22] R. Gagné and K. Medsker, "The conditions of learning: Training applications," 1996.

[23] S. Umar, I. Shaib, D. Aituisi, N. Yakubu, and O. Bada, "The effectofsocial factors on students' academic performance in Nigerian tertiary institutions," Library Philosophy and Practice (e-Journal), $\mathrm{p}$ $334,2010$.

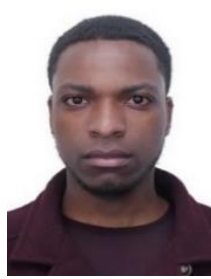

Humphrey Manhamo has obtained the bachelo degree in actuarial science from Zhejiang University of Science and Technology. He is currently a graduate student in the field of data science. His research interests include artificial intelligence and actuarial science.

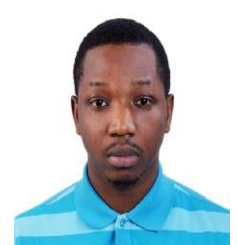

Atsou Komla Herve Agbemenou has obtained the bachelor degree in civil engineering from Zhejiang University of Science and Technology in 2017. To pursue further study, he is currently a student in Chinese language with School of Humanities and International Education. His research interest is structural engineering and in architecture.

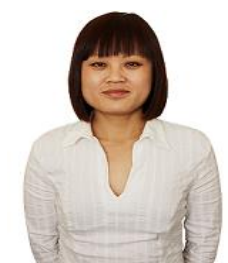

Shuhui Wu received the $\mathrm{PhD}$ degree in mathematics from London Metropolitan University in 2009. Since September 2010, she has been with School of Sciences, Zhejiang University of Science and Technology as a lecturer

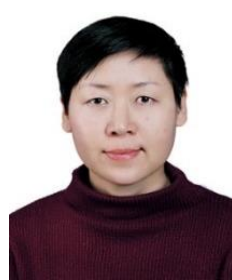

Jianhua Wei received the master degree in linguistics and applied linguistics in foreign languages from Zhejiang University in 2003. Since March 2007, she has been with International Students Affairs Center, Zhejiang University of Science and Technology as a research associate. 